\title{
Notes on the Bandeau-Texts of Columns of Kom Ombo Temple
}

\author{
Ali Abdelhalim Ali \\ Archeology Department, Faculty of Arts, Ain-Shams University, Egypt* \\ ali.abdelhalim@art.asu.edu.eg
}

\begin{abstract}
The bandeau-texts of columns in the main temple of Kom Ombo show a well prepared programm. In addition, there is a relationship between those bandeautexts of each column and the main scenes on the same column. Therefore, this paper aims to study this relationship, the format of the bandeau-texts and the programm of distribution of deities mentioned in both scenes and bandeau-texts. This study includes moreover a stylistic, phraseological and theological analysis to those bandeau-texts.
\end{abstract}

Keywords: Courtyard, hypostyle, royal propagande, Ptolemy VIII, Ptolemy XII, Tiberius, chiasmus, phraseology.

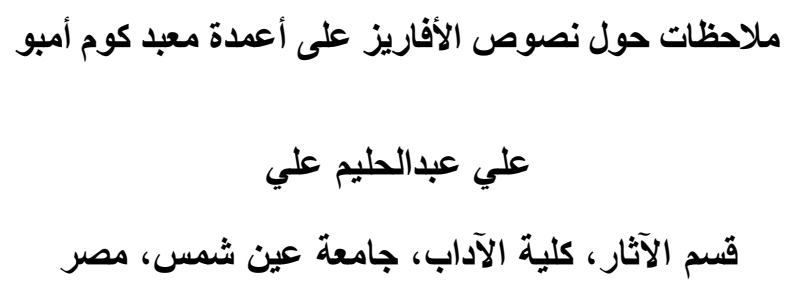

ali.abdelhalim@art.asu.edu.eg

$$
\begin{aligned}
& \text { ملخص: تحتوي نصوص الأفاريز الخاصة بأعمدة معبد كوم أمبو على برنامج مميز نم إعداده بعناية فائقة. }
\end{aligned}
$$

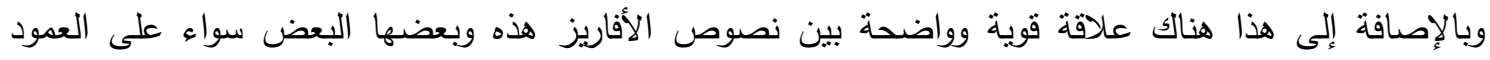

$$
\begin{aligned}
& \text { الواحد، أو مع الأعمدة الأخرى، أو حتى بين نصوص الأفاريز وبين المناظر المصاحبة لها على هذه الأعمدة. } \\
& \text { لذلك تهدف هذه الورقة البحثية إلى دراسة هذه العلاقات ومحتوى نصوص الأفاريز ومكونات هذا المحتوي، وكذلك }
\end{aligned}
$$

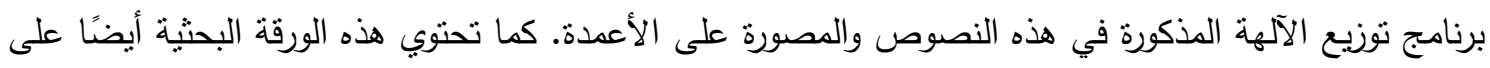

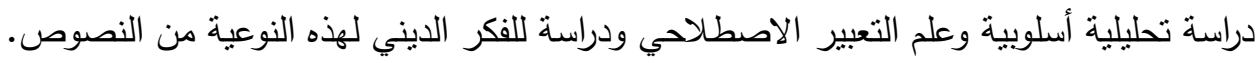

$$
\begin{aligned}
& \text { الكلمات الدالة: فناء الاحتفالات، صالة الأعمدة، دعاية سياسية، بطلميوس الثامن، بطلميوس الثاني عشر، } \\
& \text { تنييريوس، خيازموس، علم التعبير الاصطلاحي. }
\end{aligned}
$$

\footnotetext{
* I am grateful to my professors Fr. Labrique and Sh. Bedier, the directors of Kom Ombo mission, for their fruitful discussions and comments. This article has been orally presented in 'the $1^{\text {st }}$ International Conference of Dendera and Ptolemaic Studies' held at Dendera 15-17 ${ }^{\text {th }}$ March 2019.
} 


\section{Introduction:}

Bandeau-texts are scribal friezes on either walls or columns. They came into use to define the contribution of the king to a certain temple or a chamber inside it. These bandeau-texts are considered as one of the most important types of inscriptions in the Egyptian temples, as they provide Egyptologists with rich historical, cultural and religious information. The frequency of those bandeau-texts on temple walls and columns confirms their importance.

Kitchen states that 'The wall-basement bandeau-texts are first commonly attested in

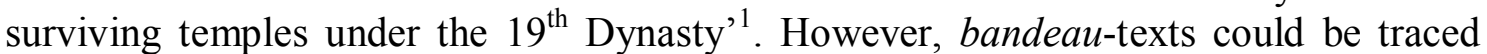
more earlier. Such examples are found on the columns of Akhenaton at Amarna ${ }^{2}$. Several instances of the bandeau-texts on columns are found during the New Kingdom, e.g. in the Karnak's great hypostyle and in Medinet Habu, both from the Ramesside period. Those bandeau-texts have been inscribed mainly on the shafts of the columns. Exceptions for bandeau-texts are attested on the capitals of columns in the Karnak's hypostyle and on the bases of the columns in the main temple of Medinet Habu ${ }^{3}$.

The bandeau-texts on columns then prevailed and became a very common topic in the Egyptian temples during the Greco-Roman period. They present a well designed decoration system like the usual topics in those temples ${ }^{4}$.

\section{General Description:}

The temple of Kom Ombo, dedicated to Haroeris and Sobek-Re, has three pillered halls like most Egyptian temples in the Greco-Roman period ${ }^{5}$. The inscriptions on the

\footnotetext{
${ }^{1}$ Kenneth Kitchen, 'A note on Bandeau texts in New Kingdom temples', in Studien zu Sprache und Religion Ägyptens: zu Ehren von Wolfhart Westendorf, überreicht von seinen Freunden und Schülern 1. ed. Friedrich Junge (Göttingen: F. Junge, 1984), 547-553.
}

${ }^{2}$ This example is also given in Yoshifumi Yasuoka, Untersuchungen zu den Altägyptischen Säulen als Spiegel der Architekturphilosophie der Ägypter, QUIA Bd. II (Hützen: Backe Verlag, 2016), pl. XIV. The oldest known hieroglyphic inscription on columns represents the royal titles of Sahure, the $5^{\text {th }}$ dynasty. Instances in Yasuoka, Säulen als Spiegel, pl. IV.

${ }^{3}$ For this instance (Medinet Habu) see Yasuoka, Säulen als Spiegel, coloured pl. V, b.

${ }^{4}$ Generally, for the decoration system and texts of the temple, especially the framing hieroglyphic columns behind both the king and the god and the ${ }^{\top} n h-d d-w 3 s$-formula, see Erich Winter, Untersuchungen zu den ägyptischen Tempelreliefs der Griechisch-Römischen Zeit (Vienna: H. Böhlau Nachf, 1968). D. Kurth followed Winter and studied the principles of the frieze-decoration at Edfu and Dendera. The aim of his research is to recognize the function of each room inside the temple by studying the friezedecorations of those rooms. Dieter Kurth, 'Die Friese innerhalb der Tempeldekoration griechischrömischer Zeit', in Aspekte spätägyptischer Kultur: Festschrift für Erich Winter zum 65. Geburtstag, ed. Martina Minas, et al. (Mainz: Philipp von Zabern, 1994), 191-201. Neither Winter nor Kurth discussed the theme of bandeau-texts on columns.

${ }^{5}$ Description is according to the sight of the god not of the visitor to the temple, as all bandeau-texts start by the ${ }^{\prime} n h$-symbol, which confronts the sanctuary. Numbers given in the publication of de Morgan are followed in the current research. de Morgan arranged the bandeau-texts on each column of the inner hypostyle (KO I, p. 354) as $a, b, c$ and $d$, while those of the outer hypostyle (KO I, p. 216) as $0, a b, c d$, ef and $g h$. Then he identified each bandeau-text with a non recurring number. This number will be used as a standard in the current study. Both inner and outer hypostyle has 10 columns from I to $\mathrm{X}$ with the following numbers: $\mathrm{KO} 481,484,487,490,493,496,499,502,505,508$. The columns of the outer hypostyle from VI correspond to XV KO 282, 285, 288, 291, 294, 297, 300, 303, 306, 309. Columns of courtyard, from I to XVI, represent numbers from KO 119 to 145 in J. de Morgan, KO I. 
columns of the courtyard ${ }^{1}$ are from the reign of Tiberius, while the columns of the outer hypostyle belong to Ptol. XII and the columns of the inner hypostyle belong to Ptol. VIII $^{2}$. The columns of both outer and inner hypostyles are better preserved than those of the courtyard. They all are 36 column excluding the columns merged in the screen walls between the courtyard and the outer hypostyle (Fig. 1). Each column contains four textual-bandeaus in addition to two decorative-bandeaus. The decorative-bandeaus illustrate plumed cartouches mounted on $n w b$-signs and protected either by vultures and seated falcon-headed lions or by cobras (Figs. 2-3).

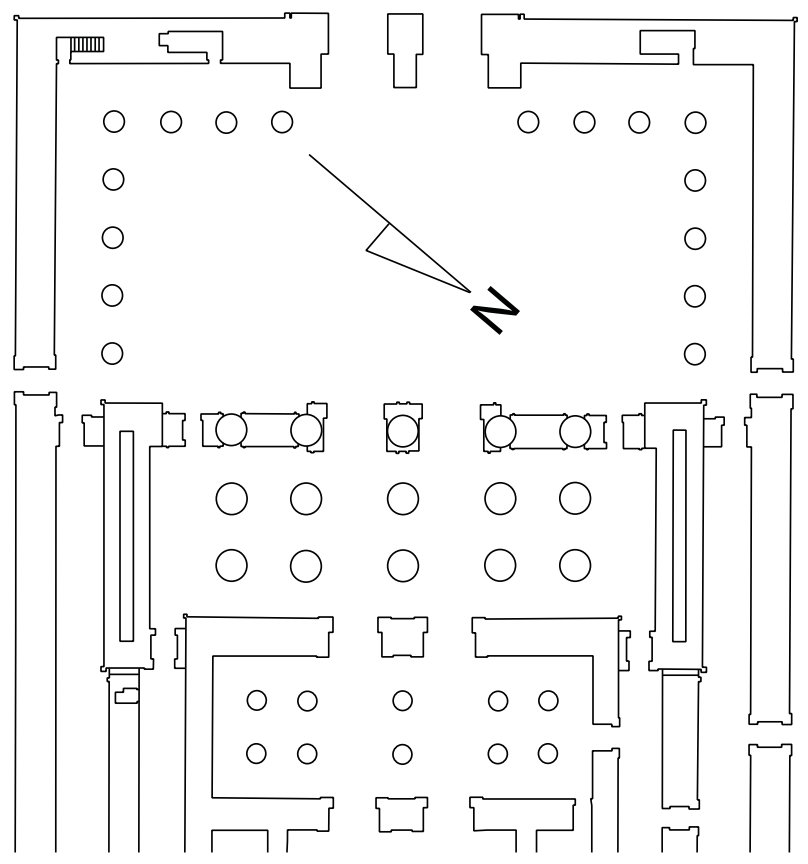

Fig. 1: columns of the halls of Kom Ombo temple. based on, PM, VI, p. 180.

TABLEAU B

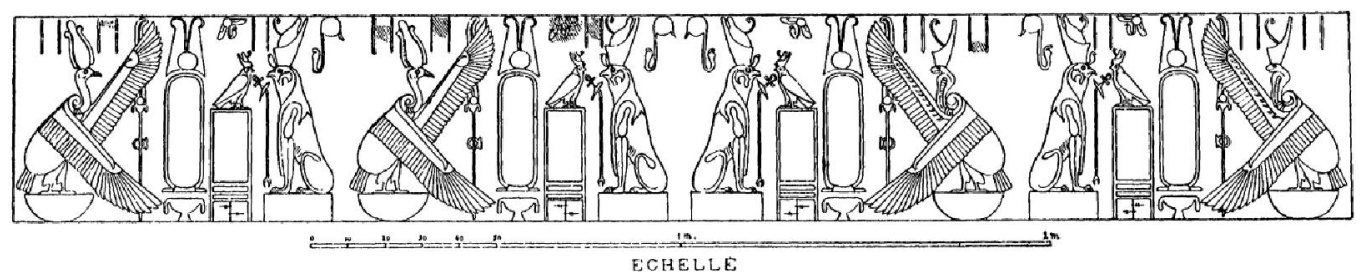

Figs. 2: decorative bandeaus, after de Morgan, KO I, p. 216.

\footnotetext{
${ }^{1}$ A. Tillier divided the scenes on the columns of the courtyard of Kom Ombo temple into four main groups. Those groups contain the struggle against enemies, creation of gods by the primordial gods of Esna, healing the left eye, rejunivation of Re by the union of Shu and Tefnut, and the final group of scenes on those columns deals with the rebirth of Sobek/Osiris at the union of the four gods: Shu, Tefnut, Geb and Nut at the funeral rituals in the necropolis 'Shed-Bag'. For details, see Anaiis Tillier, 'Les colonnes de la cour du temple de Kôm Ombo: organisation et discours théologique du décor', in Der Ägyptische Tempel als ritueller Raum: Theologie und Kult in ihrer architektonischen und ideellen Dimension, Juni 2015, ed. Stefan Baumann, at al. (Wiesbaden: Harrassowitz, 2017), 107-125.

${ }^{2}$ See for instance: Adolphe Gutbub, 'Kom Ombo', in Lexikon der Ägyptologie III (Wiesbaden: Otto Harrassowitz, 1981), 679; Günther Hölbl, Geschichte des Ptolemäerreiches: Politik, Ideologie und religiöse Kultur von Alexander dem Großen bis zur römischen Eroberung (Stuttgart: Theiss, 2004) 234.
} 


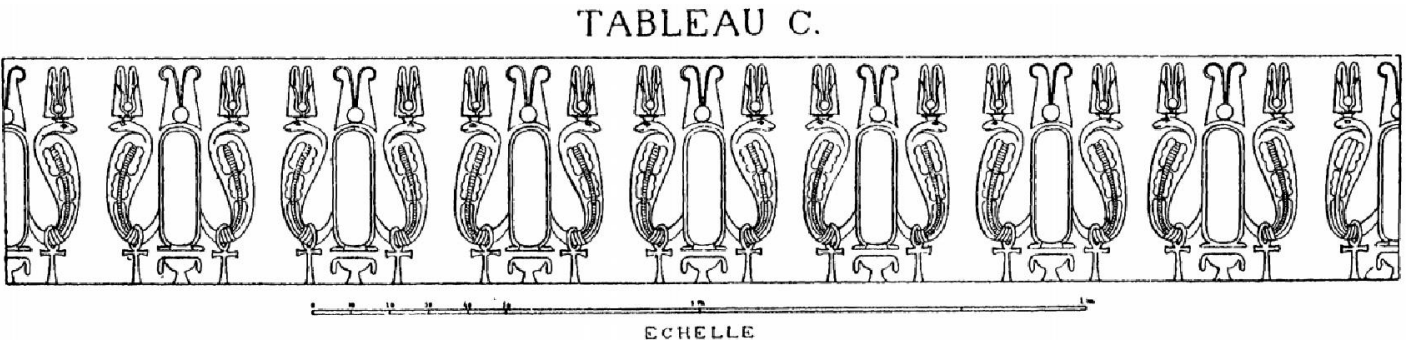

Figs. 3: decorative bandeaus, after de Morgan, $K O$ I, p. 354.

The current research focuses only on the four horizontal scribal bandeaus on the columns of Kom-Ombo temple. Each bandeau-text is divided symmetrically into two halves. Then each half moves from the center outwards. It begins always with the ${ }_{n} h$ $n \underline{t r}-n f r$-formula facing both sanctuaries of the temple and it ends by a wish. Both the ${ }^{n} h$ $n \underline{t} r-n f r$-formula and the wish are symmetric (Fig. 4).

\section{Structure of the bandeau-texts on columns of KO temple:}

As above mentioned, each bandeau-text is divided into two halves. Each half includes five phrases (Fig. 4): a symmetric enh-ntr-nfr, epithets of the king, his royal names, the king is beloved of a deity and a symmetric wish-phrase for the king. Those five phrases will be dealt with as follows:
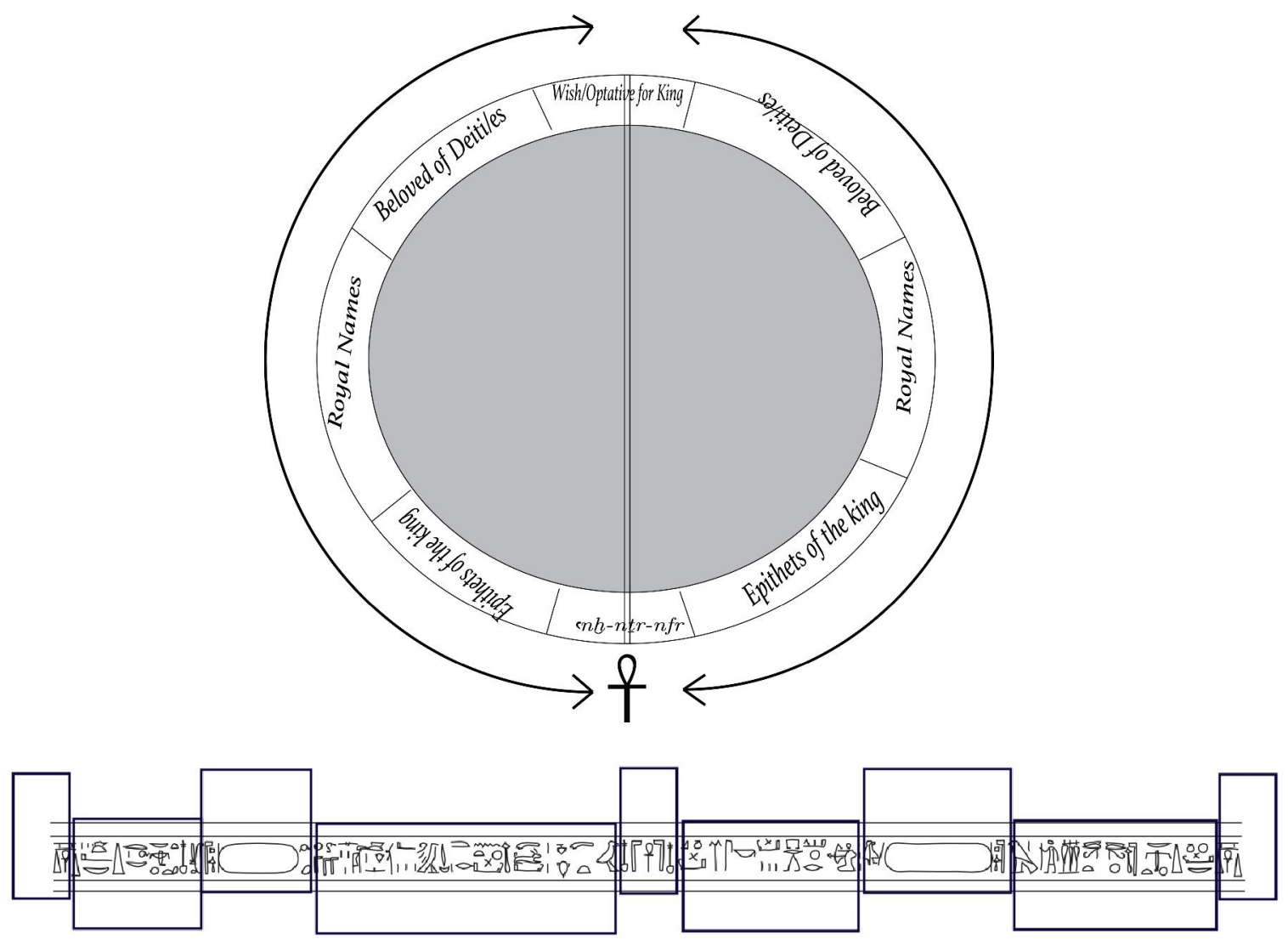

Fig. 4: Diagram for bandeau-texts moving in both directions of each column

(col. 6 of inner hypostyle). 


\begin{tabular}{|l|l|}
\hline inh & f, \\
\hline$n t r$ & 9, \\
\hline$n f r$ & 1,, \\
\hline
\end{tabular}

Table 1: the different writings of $n^{n} h, n \underline{n} r$ and $n f r$ in the bandeau-texts on columns

Attention has to be paid to the crocodile and the Hapi-figure. The crocodile as a phonetic value of the word ntr is logic and can be traced everywhere in the temples of crocodiles among which Kom Ombo is prominent ${ }^{1}$. But the phonetic value of the Hapifigure as $n f r$ is not included in the Valeurs $p$ on $^{2}$. The Hapi-figure as a phonetic value for the word $n f r$ could be due to either a confusion with the standing man whose hand holds a long stick ${ }^{3}$ or because the Nile figure is associated with fertility, which is considered as a good (nfr) thing. The second possibility is then more acceptable, as the confusion could not occur twice, as the Hapi-figure is written on both sides of the bandeau.

Notably, the ntr-nfr-phrase is replaced by both Gold- Horus- and nbty- names of Ptolemy VIII in the $2^{\text {nd }}$ bandeau-texts of columns in the inner hypostyle. Interpretation is not possible now.

\section{II.2-Epithets of the king ${ }^{4}$ :}

Several bandeau-texts describe the king as an image of gods, e.g. Re, Geb, Shu, Horus etc ${ }^{5}$. Moreover, the king is the child of some goddesses such as Hathor, Isis and Mut $^{6}$. He is also the child of certain gods such as Atum, Amun and $\operatorname{Re}^{(7)}$. He is therefore therefore the "heir" of $\mathrm{Shu}^{8}$ in reference to Geb, and "heir" of Geb himself ${ }^{9}$ in reference to Osiris. He is then the "image of Horus, beneficiant heir of Harendotes"10. Those epithets refer to the divine generations of cosmic creation in order to associate the king,

\footnotetext{
${ }^{1}$ Dieter Kurth, Einführung ins Ptolemäische: eine Grammatik mit Zeichenliste und Übungsstücken, vol. I. (Hützel: Backe Verlag, 2007), 21.

${ }^{2}$ Valeurs phon. I, OrMontp, 1990, 97.

${ }^{3}$ The standing man with the long stick in his hand is a phonetic value for nfr in Kurth, Einführung ins Ptolemäische, 130.

${ }^{4}$ For the epithets of the king in the temples of Greco-Roman Egypt see Eberhard Otto, Gott und Mensch nach den ägyptischen Tempelinschriften der griechisch-römischen Zeit: eine Untersuchung zur Phraseologie der Tempelinschriften (Heidelberg: Carl Winter, Universitätsverlag, 1964), 63-76.

${ }^{5}$ KO 148 B; 282 F-E; 481 A-B, 490 H-G; 490 G-H; 493 E-F; 505 E-F.

${ }^{6}$ KO 481 B-A; 490 F-E; 493 H-G; 496 E-F; 508 A-B.

${ }^{7}$ KO 282 E-F; 484 E-F; 493 H-G; 505 B-A. The king is the child and image of gods since early times, Otto 1964, 63-64.

${ }^{8}$ KO 499 A-B.

${ }^{9}$ KO 490 G-H.

${ }^{10} \mathrm{KO} 505$ E-F.
} 
as a divinity, with the first creator of the world (Atum) who wears the double crown too ${ }^{1}$

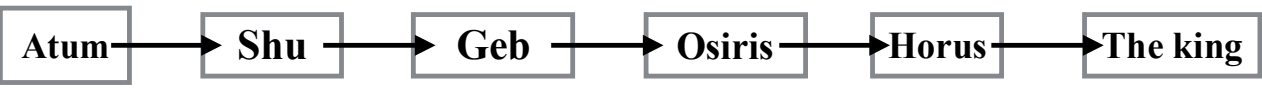

The divine generations of kingship.

The king is responsible for the offerings to all deities in their shrines and temples ${ }^{2}$. Then, he spends all the night to look for and bring those offerings ${ }^{3}$. He also obtains the incense, unguents and myrrhe from god's land to be used in these temples ${ }^{4}$. All those duries are expressed in the bandeau-texts. The "might" of the king in most bandeautexts is expressed through his following epithets: wr-phty, wsr-hnš, kni, '3-̌sfyt, nb nrw and others ${ }^{5}$. As a result for those epithets, the king is "protector, sun and sovereign of Egypt" Egypt" (b3kt and $k m t^{6}$ ) and of Nubia ${ }^{7}$ as well as of the oases ${ }^{8}$.

A royal propagande is then obvious through those phrases in the bandeau-texts of Kom Ombo temple ${ }^{9}$. The king is the beneficiant sovereign and ruler of two lands who protects Egypt and its people ${ }^{10}$. Moreover, some epithets refer to the king as judge and

\footnotetext{
${ }^{1}$ This divine royal generation is very obvious in several documents. Some documents give details about how the throne is transferred from each god to his successor. See for example the naos of Saft el-Henneh in George Goyon, 'Les Travaux de Chou et les Tribulations de Geb', in Kemi 6 (1936), 1ff; Shafia Bedier, Die Rolle des Gottes Geb in den ägyptischen Tempelinschriften der griechisch-römischen Zeit. Hildesheimer Ägyptologische Beiträge 41 (Hildesheim: Gerstenberg 1995), 198-199. In KO 70, it is said about Domitian, that he took the office of Shu, the throne of Geb and the testament of Osiris.
}

${ }^{2}$ The king is also provider of food and consequently guarantee of life for his people. cf. Otto, Gott und Mensch, 63-64. The king has obtained this rule as he is the heir of Geb see Bedier, Gottes Geb, 173ff.

${ }^{3}$ KO 303 E-F. Compare the same function in an offering of Maat in Edfu VIII, 6, 13.

${ }^{4} \mathrm{KO} 309 \mathrm{G}-\mathrm{H}$. It is noted here that this phrase is located on the southern half of the column. This location location fits so well with the location of god's land. For god's land and its location in the eastern desert and south-east of Egypt see Abdelaziz Saleh, 'Notes on the Ancient Egyptian ta-netjer, 'God's-Land', in BIFAO 81 (1981), 110; Rainer Nutz, 'Zur ideologischen Verortung von t3-ntr und Punt', in SAK 39, (2010), 281-288; Stefan Baumann, Schatzkammern. Ihre Dekoration und Raumkonzeption in ägyptischen Tempeln der griechisch-römischen Zeit, SSR 19 (2018), 242-243, 370-373; Demetri Meeks, 'Coptos et les chemins de Pount', in TOPOI Suppl. 3 (2002): 267-335.

5 e.g. KO 484 G-H; 493 A-B; 496 A-B; F-E; 133 C-D.

${ }^{6}$ e.g. KO 487 A-B; 502 G-H; 505 H-G. Also in Edfu, the king is the sun of Egypt (b3kt) cf. Edfu II, 87, 13 (bandeau-text). For Egypt as b3kt and kmt (the duzzling- and the black eye) see Eberhard Otto, 'Ägypten im Selbstbewußtsein des Ägypters', in Lexikon der Ägyptologie I (Wiesbaden: Otto Harrassowitz, 1975) 76.

${ }^{7} \mathrm{KO} 487$ E-F.

${ }^{8}$ KO 502 H-G.

${ }^{9}$ Since the palette of Narmer onwards, the temple is the most suitable place to point out the political events of the king. Most scenes and texts show how the king is the savior of the country and garantee of peace as well as social and cosmic order. For the temple as political center for the king see, Rolf Gundlach, "Ich gebe dir das Königtum der Beiden Länder": der ägyptische Tempel als politisches Zentrum', in 5. Ägyptischen Tempeltagung: Würzburg, 23-26. September 1999, ed. Horst Beinlich, et al. (Wiesbaden: Harrassowitz 2002), 91-108.

${ }^{10}$ KO 303 C-D; 279; 294 A-B; 309 H-G. In KO 603, Haroeris calls the king as 'father of $\mathrm{Pa}^{c} t$, mother of Rekhyt, nurse of Henmemt ... ' translation after Otto, Gott und Mensch, 64. 
vizier $^{1}$ in order to rule over Egypt according to the principle of Maat. The king is therefore impartial $\left(m 3^{c}-i b\right)$, free from falsehood and he practices Maat for gods and goddesses $^{(2)}$. Practicing Maat is one of the most necessary duties of the king. He is then described as 'he who practices Maat for Re and offers it in front of him every day' in the $2^{\text {nd }}$ bandeau-text of column XIII in the outer hypostyle ${ }^{3}$. He also loves Maat and his $K a$ hates partiality ${ }^{4}$. With the sistra in his hands, the king appeases the distant goddess as one of his duties associated with judge and vizirate ${ }^{5}$.

\section{II.3- The Royal (coronation and birth) Names:}

The coronation and birth names represent the $3^{\text {rd }}$ theme of the bandeau-texts. They are systematically written inside two cartouches. The coronation name is allocated on one side and the birth name on the other side. In contrast to the inner hypostyle, both the courtyard and outer hypostyle have a regular system for allocating those names ${ }^{6}$. The coronation name is positioned on the southern sides of the columns of the courtyard and the outer hypostyle, while the birth name on the northern sides. Some exceptions however are found in the bandeau-texts of three columns of the courtyard; col. 9, 11 and 12 , where the coronation name is written on the northern halves ${ }^{7}$.

As for the distribution of the royal names in the inner hypostyle (Fig. 5), columns could be divided into three groups: regular, mutual and random. The $1^{\text {st }}$ group includes the southern four columns 4, 5, 9 and 10. This group allocates both royal names regularly but in contrast to the courtyard and the outer hypostyle. The coronation name is situated on the northern half and the birth name on the southern half of this group ${ }^{8}$. The $2^{\text {nd }}$ group includes the central and the two northern columns. This $2^{\text {nd }}$ group of the columns allocates the royal names mutually. Columns 3 and $8^{9}$ use the birth name in the the northern half of the $1^{\text {st }}$ and $3^{\text {rd }}$ bandeau-texts, while the coronation name in the southern and vice versa for the $2^{\text {nd }}$ and $4^{\text {th }}$ bandeau-texts. Columns 1 and $6^{10}$ followed this mutual system but conversed, i.e. the northern side of those both columns allocated the coronation name in the $1^{\text {st }}$ and $3^{\text {rd }}$ bandeau-texts and the birth name in its $2^{\text {nd }}$ and $4^{\text {th }}$ bandeau-texts. The $3^{\text {rd }}$ group contains columns 2 and 7 , where the royal names are positioned randomly.

\footnotetext{
${ }^{1}$ Both judge and vizierate are associated with the king from ancient times. For the judicial role of the Egyptian king see Bernadette Menu, 'Aspects de la fonction de juger dans l'Égypte pharaonique', in Droit et cultures 47 (1), (2004): 123-138; Otto, Gott und Mensch, 75-76.

${ }^{2}$ KO 285 H-G cf. Otto, Gott und Mensch, 127.

${ }^{3} \mathrm{KO} 303$ C-D.

${ }^{4} \mathrm{KO} 297 \mathrm{G}-\mathrm{H}$.

${ }^{5} \mathrm{KO} 285$ C-D. Tasenetnefret is meant here.

${ }^{6}$ Note the same on the columns of Philae (vol. III) and Edfu (vols. II and III).

${ }^{7}$ Respectively, KO 145, $151 \mathrm{C}-\mathrm{D}, \mathrm{E}-\mathrm{F}$ and $154 \mathrm{~A}-\mathrm{B}$.

${ }^{8} \mathrm{KO}$ nrs. 490, 493, 505 and 508.

${ }^{9} \mathrm{KO} 487$ and 502. However, an exception is found in the southern side of col. 3, where the coronation name is written three times on this side like in the outer hypostyle.

${ }^{10} \mathrm{KO} 481$ and 496.
} 

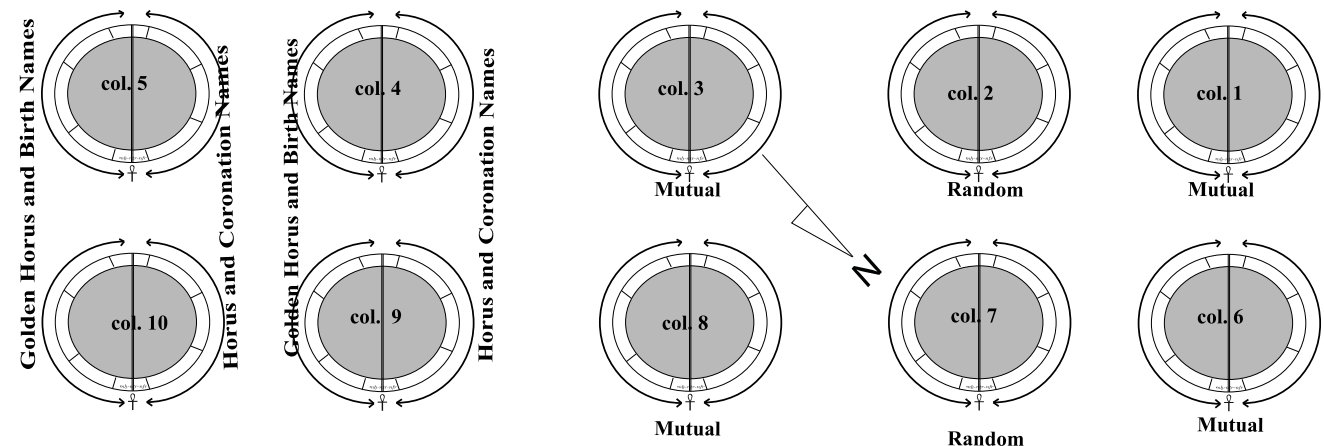

Fig. 5: Allocating the royal names on both halves of columns of the inner hypostyle of Kom Ombo.

The $2^{\text {nd }}$ bandeau-text of the columns in the inner hypostyle is distinguished. Both royal titles of Ptolemy VIII are followed by the cartouches of Cleopatra II and III as his sister and his wife respectively ${ }^{1}$. The name of Cleopatra II is associated with Horus- and and the Coronation name of Ptolemy VIII, while the name Cleopatra III is associated with his Gold- Horus- and Birth names ${ }^{2}$.

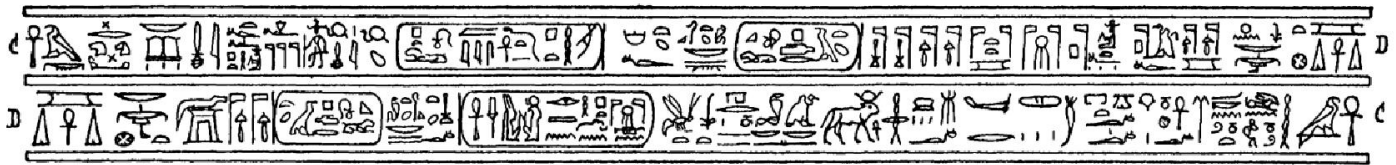

\section{Hieroglyphic Text 2: $2^{\text {nd }}$ bandeau-text in the inner hypostyle showing the cartouches of Ptol. VIII followed by his wives.}

In addition, the northern four columns differ here from the central and southern group at allocating the names of both Cleopatras. Cleopatra II is mentioned on the southern halves of the columns of the northern group and on the northern half of the central and the southern group. Followed by the names of her grandfathers Ptolemies II - VI, Cleopatra III occupied the rest locations except for the southern halves of columns 5 and 10. Her name is missing from these both columns (Fig. 6). However, the names of Ptolemies II - VI are written.
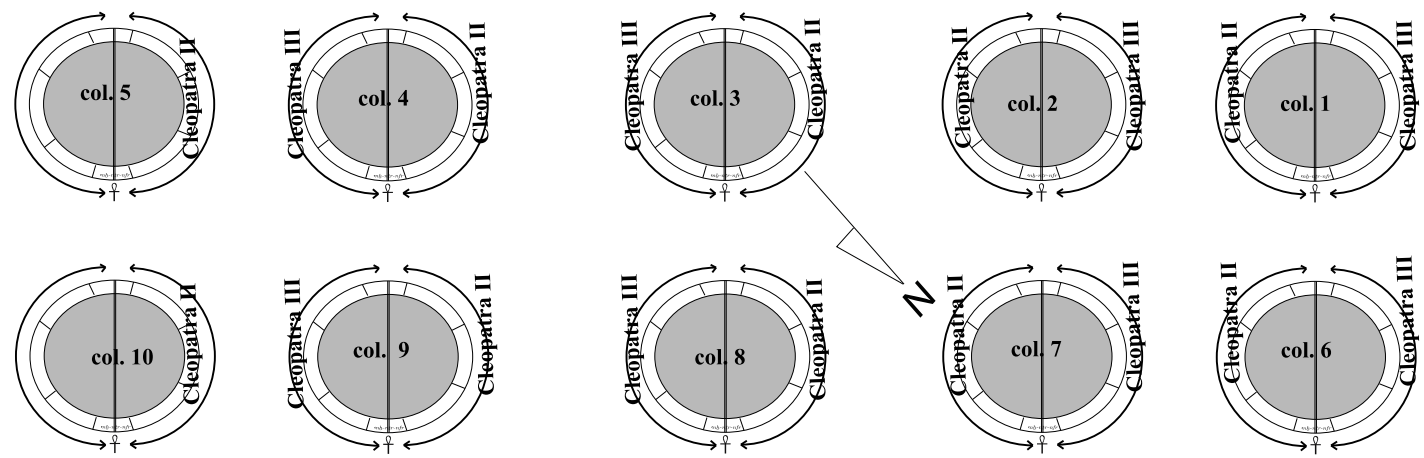

Fig. 6: Names of Cleopatra II and III in columns of the inner hypostyle.

\footnotetext{
${ }^{1}$ Cleopatra II is the $1^{\text {st }}$ wife of Ptolemy VIII and Cleopatra III is his $2^{\text {nd }}$ wife. Cf. Heinz-Joseph Thissen, 'Kleopatra', in Lexikon der Ägyptologie III (Wiesbaden: Otto Harrassowitz, 1981): 452-453.

2 Cf. Martina Minas, 'Die Dekorationstätigkeit von Ptolemaios VI. Philometor und Ptolemaios VIII. Euergetes II. an Ägyptischen Tempeln (Teil 2)', in OLP 28 (Leuven: Peeters, 1997): 99.
} 
Minas noticed the absence of Cleopatra III's name only from column 5 of the inner hypostyle. Minas supposed that it was not intentional. She understood this absence as an epigraphic error by J. de Morgan or even as a graphic error in the original texts. The original texts have been revised by the author of this article and they have no error ${ }^{1}$.

Cleopatra II is absent on Edfu's famous document, where only Cleopatra III follows Ptol. VIII. This case of Edfu could have happened during the conflict in the family members ${ }^{2}$. Both Ptol. VIII and Cleopatra III were against Cleopatra II. Therefore, Ptol. VIII neglected the name of Cleopatra II in Edfu document. The case of Kom Ombo is inversed, i.e. the name of Cleopatra III is missing. Historical sources refer to the flee of Cleopatra III to Cyprus from $130 \mathrm{BC}$ to $127 \mathrm{BC}^{3}$. That means, the missing of her name could date back to that period as a political reason like that of Edfu.

\section{II.4- The king as beloved of a deity ${ }^{4}$ :}

Behind the royal names comes the $4^{\text {th }}$ phrase of the bandeau-texts on the columns of Kom Ombo temple. This phrase is $m r y-n$ (beloved of) + name of a deity. It occurs in all bandeau-texts without exception in reference to the king as beloved of a deity mostly depicted in front of him in the main scene of the same column. The inner hypostyle represents the king in front of a single deity in the main scene, while both the outer hypostyle and the courtyard represent him in front of two divinities.

In most cases of the lower $/ 1^{\text {st }}$ bandeau-text, the king is beloved of the deity, to whom the king offers in the main scene above this $1^{\text {st }}$ bandeau-text ${ }^{5}$. The $2^{\text {nd }}$ bandeau-texts of the outer hypostyle and the courtyard contain the name of the $2^{\text {nd }}$ deity of the main scene.

Based on the latter note, the phrase 'beloved of a deity' in the $1^{\text {st }}$ bandeau-text represents the key-phrase to identify the deity in the main scene. This conclusion could be moreover applied in recognizing the destroyed figures or names of deiti/es either depicted in the main scenes or written in the $1^{\text {st }}$ and $2^{\text {nd }}$ bandeau-texts.

This system of recognizing the dieties through the phrase 'beloved of a deity' has been noticed also on the columns of other greco-roman temples, e.g. the eastern

\footnotetext{
${ }^{1}$ Minas, 'Dekorationstätigkeit', 99, n. 46. Ptol. VIII is accompanied by his wives on the walls of Kom Ombo temple. In the soubassements, he is followed by only one on each side of the temple for symmetry.

${ }^{2}$ Cf. Hölbl, History of the Ptolemaic empire, 192.

${ }^{3}$ Hölbl, History of the Ptolemaic empire, 197; Stefan Pfeifer, Die Ptolemäer im Reich der Kleopatra (Stuttgart: W. Kohlhammer, 2017), 159. Pfeifer dates that flee by 131/132 BC.

${ }^{4}$ Since the $5^{\text {th }}$ Dynasty, Niuserre has been described as 'beloved of Uto and Nekhbit' on his columns from Abusir: see Yasuoka, Säulen als Spiegel, 52 (1.10). Montuhotep II is 'beloved of Month' on his columns too, Yasuoka, Säulen als Spiegel, 118 (2.26). The phrase 'beloved of a deity' then became usual in the bandeau-texts of columns at least since the reign of Ramesses II. Most known examples are attested in the great hypostyle of Karnak (e.g. OIP 107, p. 122, n. 20). The phrase 'beloved of + a deity', refering to the king, could be generated from the popular phrase 'beloved of his lord' for the individuals since the early Old Kingdom.

${ }^{5}$ However, three exceptions are recorded on columns of inner hypostyle: Hathor is depicted in the main scene of column 5 (KO 492: southern half), while the king is beloved of her child Khonsu (KO 493 B-A). On the southern half of column 9 (KO 504), Panebtaui is depicted in the main scene, while the king is beloved of Hathor (KO $505 \mathrm{~B}-\mathrm{A}$ ). The northern side of column 10 (KO 506) represents Khonsu in its main scene, while the king is beloved of Haroeris (KO $508 \mathrm{~A}-\mathrm{B}$ ).
} 
colonnade of Philae used the same phrase but only in its lower bandeau-texts ${ }^{1}$. The columns of Edfu used this system for the lower und upper bandeau-texts ${ }^{2}$.

In addition to the previous note, deiti/es mentioned in all bandeau-texts on columns of Kom Ombo temple have been combined together on each column. A family relationship is regarded not only on the bandeau-texts of each half of one column but also between neighbouring columns. Three examples will be discussed here (A, B and C).

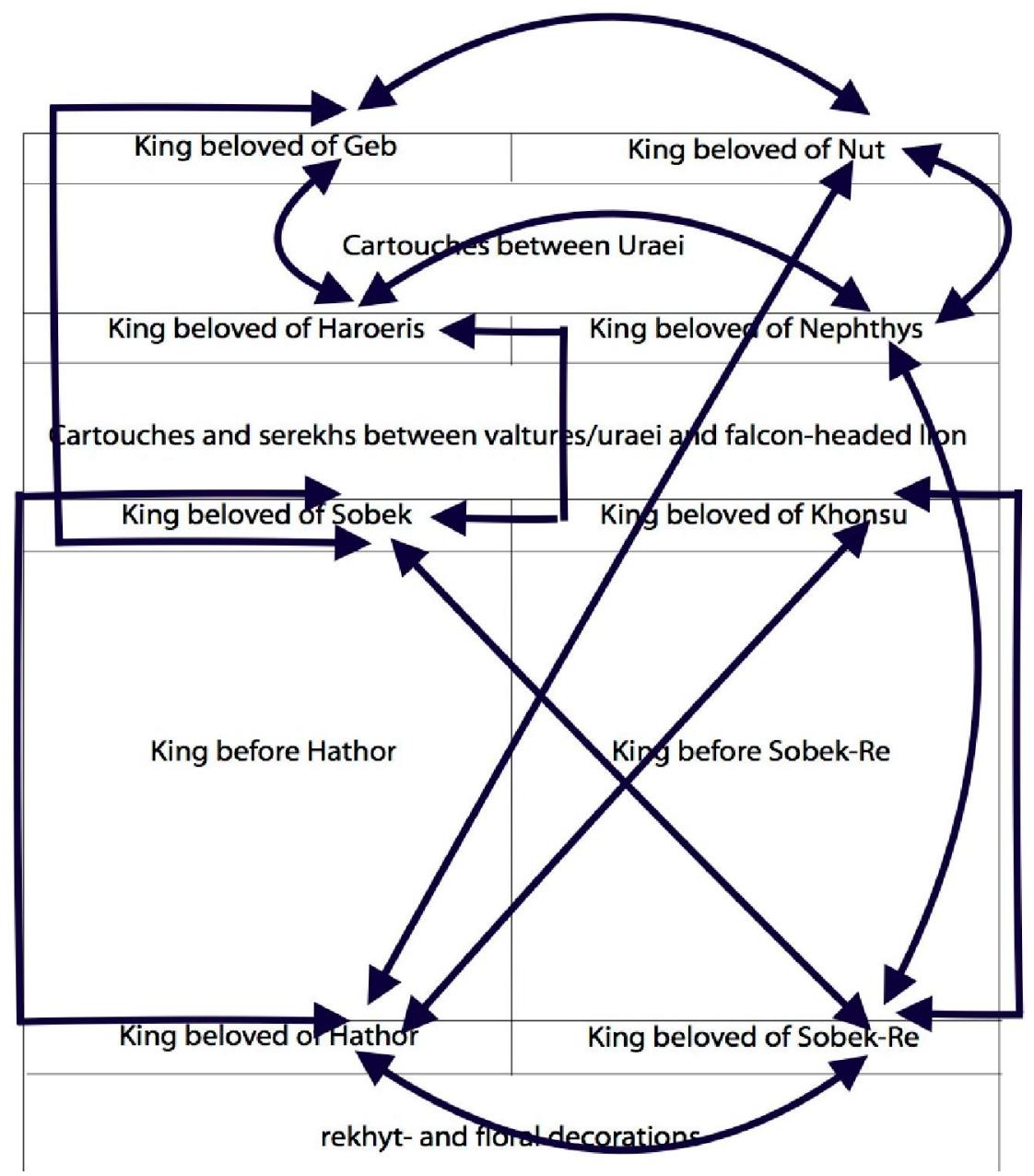

Fig. 7: Diagram for the various possibilities of the relationship between bandeaus on one column.

A. As the diagram in Fig. 7 illustrates, a strong relationship has been set in all bandeau-texts of the one column as well as with other bandeau-texts in other columns. The given example is the $1^{\text {st }}$ column in the inner hypostyle ${ }^{3}$. The $1^{\text {st }}$ bandeau-text mentions that the king is beloved of Sobek-Re on one side and of his consort Hathor on the other side. The $2^{\text {nd }}$ bandeau-text mentions that the king is beloved of their child Khonsu, i.e. the three members of Sobek-Re's triad. In the $4^{\text {th }}$ bandeau-text, the king is

\footnotetext{
${ }^{1}$ e.g. the eastern colonnade at Philae III 2, pl. 5-24.

${ }^{2}$ Cf. Edfu III, pp. 229-289.

${ }^{3} \mathrm{KO} 479-481$.
} 
beloved of Geb and Nut in an opposite position to Sobek-Re and Hathor in the $1^{\text {st }}$ bandeau-text to show an evenness in a chiasmic way. The children of Geb and Nut, Haroeris and Nephthys, are mentioned beneath them i.e. in the $3^{\text {rd }}$ bandeau-text. Since Sobek-Re is identified with Geb and Hathor with Nut (sky) ${ }^{1}$, both Haroeris and Nephthys could be considered as children of Sobek-Re and Hathor, again a reference to the family of Sobek-Re in the same column.

B. The northern half of col. $8^{2}$ of the outer hypostyle mentions Shu (=Haroeris) in its $1^{\text {st }}$ bandeau-text (Fig. 8), while his partner Tefnut-Tasenetnefret is mentioned in the $2^{\text {nd }}$ bandeau-text. The southern half of the same column ${ }^{3}$ has Sobek-Re $(=\mathrm{Geb})$ in its $1^{\text {st }}$ bandeau-text and his consort Hathor (=Nut) in the $2^{\text {nd }}$ bandeau-text. The $3^{\text {rd }}$ bandeautext of this column has Haroeris on its both sides. Osiris and Isis are mentioned in the $4^{\text {th }}$ bandeau-text. Then the three generations of Heliopolis are present here.
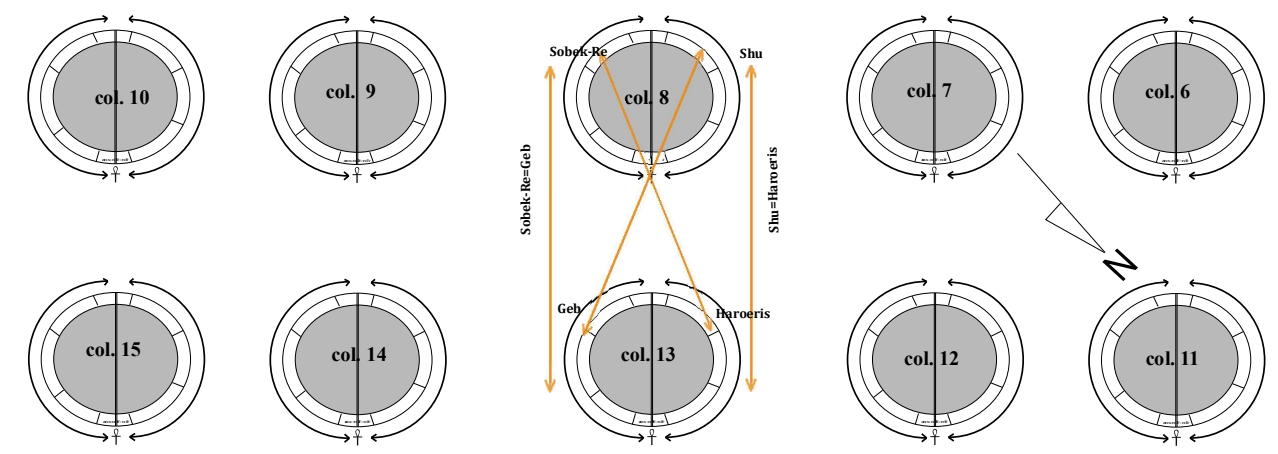

\section{Fig. 8: Chiasmus and parallelism between the names of gods in the bandeaus-texts in the central columns of the outer hypostyle.}

C. Col. 13 is closed to column 8 and has a very similar system (Fig. 8). The triad of Haroeris, containing his consort Tasenetnefret and their child Panebtaui, is respectively mentioned in the lower three bandeau-texts of the northern half (north axis). The lower three bandeau-texts of the southern half (south axis) contain Geb (=Sobek), Nut (=Hathor) and Sobek-Re.

Both columns 8 and 13 separate the two axes of the temple. Therefore, their bandeau-texts are well concerned and combined together. Chiasmus and parallelism are regarded here (Fig. 8). In a chiasmic way, the triad of Sobek-Re on the southern half of col. 8 matches his copartner (Haroeris) on the northern half of col. 13 and vice-versa. On the other hand, the southern half of both columns has Sobek-Re and Geb who are equal. This side is parallel to the northern half where Shu and Haroeris are attested.

\footnotetext{
${ }^{1}$ For the identification of Shu with Haroeris, Geb with Sobek, read KO 194, 901 and KO 926. In both foundation texts 901 and 926, Sobek and Geb are syncretized (cf. KO 930). Then, Geb is identified with Sobek at Kom Ombo and in the Greek documents from Fayum. As the name of Sobek has been given to Geb, i.e. Sobek is the Ka of Geb. Both are very associated to land/earth and fertility. Cf. Adolphe Gutbub, Textes fondamentaux de la théologie de Kom Ombo I (BdE 47), (Cairo: IFAO, 1973), 479 n. (j); Hermann Kees, Der Götterglaube im alten Ägypten, $2^{\text {nd }}$ ed. (Berlin: Akademie-Verlag 1956), 435; Jean Yoyotte, 'Processions géographiques mentionnant le Fayoum et ses localités', in BIFAO 61 (1962): 90 n. 3.

${ }^{2} \mathrm{KO} 286$.

${ }^{3} \mathrm{KO} 287$.
} 


\section{II.5-The wish for the king:}

As the king is beloved of deities, the last item of each bandeau-text represents a wish to him. A symmetric sign has been chosen to finalize both sides of the bandeau-texts just like the $1^{\text {st }}$ phrase of bandeau-texts ('nhh-ntr-nfr).

In most bandeau-texts, the common wish to the king is di-`nh "given life" ${ }^{1}$. This phrase recalls $n h$-ntr-nfr in the beginning. As both phrases contain a wish to the king at the beginning and end of each bandeau-text that "he may live".

The king is frequently wished to be "given life, appearance/crowns (also like Re every day), all prosperity, happyness, health" etc ${ }^{2}$. The king is also the "lord of life, stability and dominion, 3 . In other cases, he is wished to "appear as a king of Upper and Lower Egypt on the throne of Horus foremost of living souls"4. The last long phrase occurs only in the lower bandeau-texts of columns of the outer hypostyle and also the lower bandeau-texts of only four columns $(2,3,7$ and 8$)$ of the inner hypostyle, which represent the axis of Haroeris. This limitation for the axis of Haroeris in the inner hypostyle could refer to his kingship like Horus.

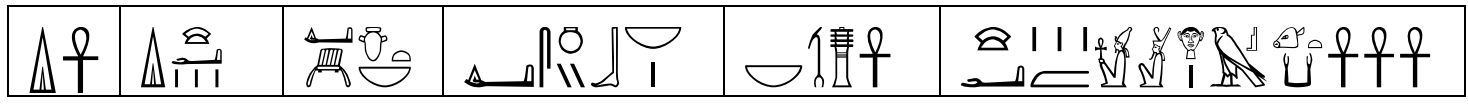

Table 2: The various wishes for the king in each bandeau-text.

Unlike the other halls, the inner hypostyle has variety of wishes. The outer hypostyle has regularly only two phrases: $h^{\top} w$ mi $r^{\ulcorner}---h n t{ }^{\top} n h w$ in its lower bandeau-texts and di${ } n h$ in the other three bandeau-texts. From the remaining bandeau-texts in the courtyard, it seems that the wish $d i-{ }^{\top} n h$ has been used in all cases.

\section{General commentary:}

III.1- A strong relationship has been established between both phrases before and after the cartouches, namely between the epithets of the king and the deity of whom the king is beloved. Such meaningful relationship could be highlighted in the next few examples:

- The $1^{\text {st }}$ bandeau-text of $2^{\text {nd }}$ column in the inner hypostyle ${ }^{5}$ contains both children of the sun-god, Shu and Tefnut as deities of whom the king is beloved. In this bandeautext, the epithets of the king mention that he rises with the crown of Lower Egypt on his

\footnotetext{
${ }^{1}$ The phrase $d i-{ }^{-} n h$ is strongly associated with the king. It follows another phrase ir.f in several cases. see John Gee, 'A New Look at the di-'nh Formula', in Acts of the Tenth International Congress of Demotic Studies: Leuven, 26-30 August 2008, ed. M. Depauw et al., (Leuven-Paris-Walpole, 2014), 73-82; Peeter Beylage, 'Die Formel $\operatorname{ir}(i)=f \underline{d}(i)$ ' $n h$ in den Texten der 18. Dynastie', in $G M 181$ (2001), 19-26; Emely Teeter, The presentation of Maat: ritual and legitimacy in ancient Egypt, SAOC 57 (Chicago: The Oriental Institute of the University of Chicago, 1997), 55-68.

${ }^{2}$ Oldest example could be attested behind the royal title of Senefru: Urk. I, 8, 1.

${ }^{3} \mathrm{KO} 496 \mathrm{H}$.

${ }^{4} \mathrm{~Wb} . \mathrm{V}, 90,8$.

${ }^{5} \mathrm{KO} 484 \mathrm{~A}-\mathrm{B}$ and B-A.
} 
head as 'great of magic'. The term 'great of magic' refers to the crown ${ }^{2}$ and in the same time it represents one of the most important epithets of Shu ${ }^{3}$. Likely, the king is described as 'he who adores Usret (the mighty goddess), which is in fact another form of Tefnut. Both words (wer-heka and Usret) are associated with the legend of the return of the distant goddess ${ }^{4}$. It is her brother Shu, who brought her to Egypt according to the command of their father, the sun-god.

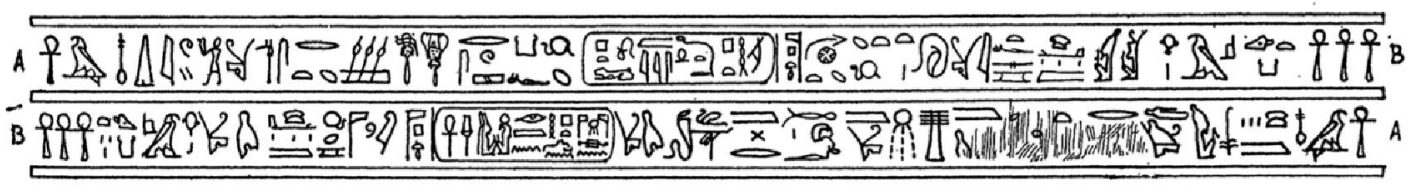

Hieroglyphic Text 3: $1^{\text {st }}$ bandeau-text of the $2^{\text {nd }}$ col. of the inner hypostyle.

- Another example could be provided here from the $1^{\text {st }}$ bandeau-text of the $1^{\text {st }}$ column of the inner hypostyle too. The epithets of the king refer to him as the image of Geb and the child of Axt-goddess. On this bandeau-text, the king is beloved of both Sobek-Re (=Geb) andHathor (=Axt-goddess $)^{5}$.

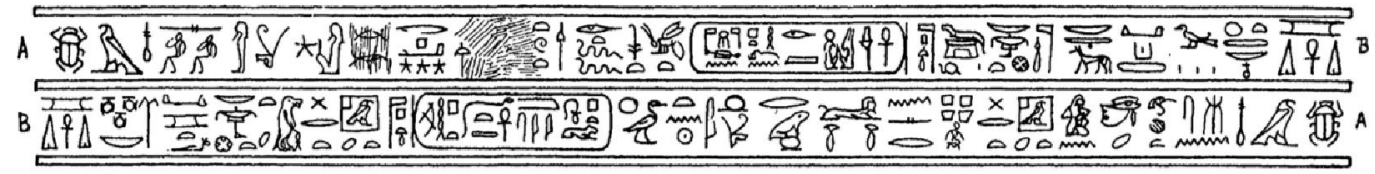

Hieroglyphic Text 4: $1^{\text {st }}$ bandeau-text of the $1^{\text {st }}$ col. of the inner hypostyle

- In the $1^{\text {st }}$ bandeau-text of column VII of the outer hypostyle ${ }^{6}$, it is said about the king that he "who fills the eye of Horus with its necessaries, who places the right and left eyes for their lord'. Those epithets suit the epithet of the king after the cartouche in the same bandeau-text. As the king is beloved of Haroeris lord of wdjaty. Moreover, the word 'wedjaty' refers to the cult of Haroeris and to his two eyes in the same time'.

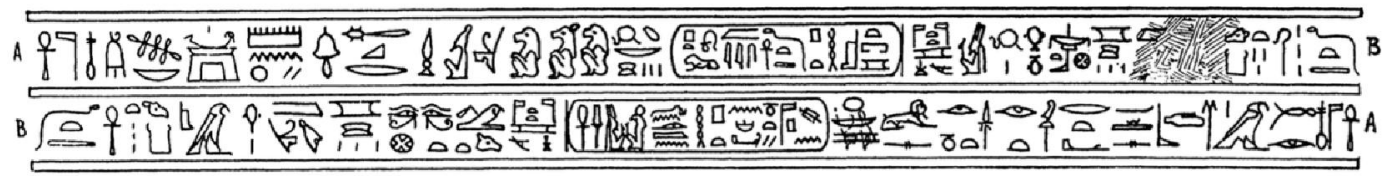

Hieroglyphic Text 5: $1^{\text {st }}$ bandeau-text of the $7^{\text {th }}$ col. of the outer hypostyle

\footnotetext{
${ }^{1}$ The king as 'great of magic' in Leitz, $L G G$ II, p. 454 (18 and 52).

${ }^{2} \mathrm{~Wb} \mathrm{I}, 328.6$.

${ }^{3}$ Heka/magic changes roles with Shu in various sources. Both are creative powers of magic, see Geraldine Pinch, Magic in Ancient Egypt (London: British Museum Press 1994), 28.

${ }^{4} \mathrm{KO} 484$ A-B. The same context exists in the $1^{\text {st }}$ bandeau-text of column 7 of the inner hypostyle (KO 499 A-B). This text confirms the relationship between Khonsu and the king, who fills the eye, i.e. the moon in reference to the distant goddess as well. For the role of Shu and Tefnut in the legend of the distant goddess see Pinch, Magic, 24f.

5 cf. Leitz, LGG I, p. 27 (24, 45-46, 48-49, 60-61, 84, 88, 131).

${ }^{6} \mathrm{KO} 285$ B-A.

${ }^{7}$ cf. Gutbub, Textes Fondamentaux, I, 80-82.
} 
- It is not surprising to read in the $2^{\text {nd }}$ bandeau-text of the same column ${ }^{1}$ that the king adores the mighty goddess, while he shakes the sistra in his hands in order to praise her $\mathrm{Ka}$ '. These epithets of the king are very close to the name of Tasenetnefret, of whom the king is beloved. Here is again an allusion to the role of the king to appease the distant goddess.

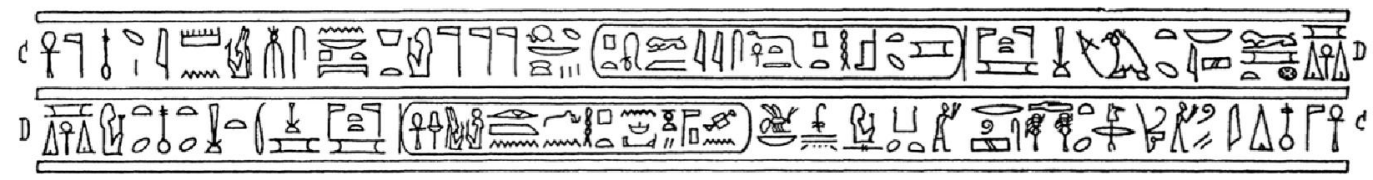

Hieroglyphic Text 6: $2^{\text {nd }}$ bandeau-text of the $7^{\text {th }}$ col. of the outer hypostyle.

-The final example comes from the $2^{\text {nd }}$ bandeau-text of column $\mathrm{X}$ in the outer hypostyle $^{2}$. The king is the heir of Geb and child of Nut, then he is identified with Osiris. The phrase behind the cartouche mentions that he is beloved of Nephthys, the sister of the god Osiris.

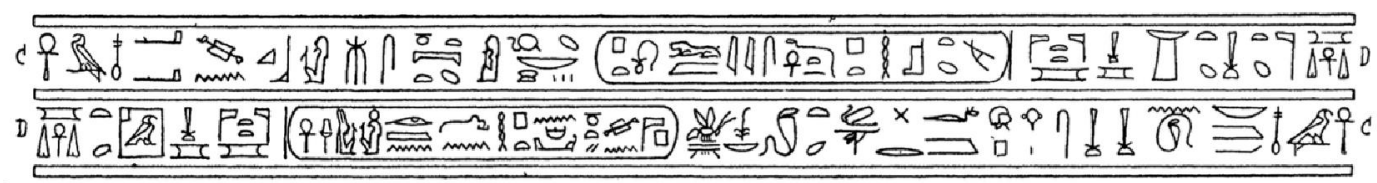

Hieroglyphic Text 7: $2^{\text {nd }}$ bandeau-text of the $10^{\text {th }}$ col. of the outer hypostyle.

All the above examples refer to the coherent relationship between each theme and the other inside one bandeau-text. In addition, a complementarity has been observed between those bandeau-texts on both halves of each column in Kom Ombo temple.

III.2- It is also noted, that several phrases are literally copied from a bandeautext to the other, either in the same hall or from the inner to the outer hypostyle and then to the courtyard. Two examples will be given here.

The $1^{\text {st }}$ example of these phrases is 'giving the adoration to Usret and holding the sistra to praise her Ka' in reference to Tefnut and Tasenetnefret. These phrases occur in the $1^{\text {st }}$ bandeau-text of column 2 in the inner hypostyle ${ }^{3}$. They are copied in the $2^{\text {nd }}$ bandeau-text of column VII of the outer hypostyle ${ }^{4}$ and then in the $1^{\text {st }}$ bandeau-text of column IV of the courtyard ${ }^{5}$. It is worthy noticed that these epithets occur on the $2^{\text {nd }}$ column of both hypostyles and the $4^{\text {th }}$ column of the courtyard, i.e. on the side of Haroeris and his consort Tasenetnefret who is accentuated in these epithets.

The $2^{\text {nd }}$ example of phrases copied in several bandeau-texts from inner to outer hypostyle describes the king as 'child of Amun, born of Mut mistress of sky' ${ }^{6}$, which has has been transcribed literally from the $4^{\text {th }}$ bandeau-text of column 5 of the inner

\footnotetext{
${ }^{1} \mathrm{KO} 285$ D-C.

${ }^{2}$ KO 294 C-D.

${ }^{3} \mathrm{KO} 484$ A-B.

${ }^{4}$ KO 285 D-C.

${ }^{5}$ KO 130 B-A.

${ }^{6}$ KO 493 H-G.
} 
hypostyle to the $2^{\text {nd }}$ bandeau-text of column XV of the outer hypostyle ${ }^{1}$. It has been recopied to the $2^{\text {nd }}$ bandeau-text of column VII in the outer hypostyle but omiting the word $\mathrm{Mut}^{2}$. These epithets of the king could have been then transferred to the courtyard but the bad and ruined state of this courtyard can not help to support this theory.

III.3- Generally, one could notice a difference between the system of work in both the courtyard and the outer hypostyle from one side and the inner hypostyle from the other side. As the latter has no regular system like the two other halls. This could due to the irregular work in the inner hypostyle. One could assume that the political events after Ptol. VI affected the continuity of the decoration program of the inner hypostyle. After he built this inner hypostyle, Ptol. VI started the decorations but the work stopped during the conflict between the ptolemaic family members and then pursued during the reign of Ptol. VIII.

\section{To sume up:}

Since the king is the main character in all themes of the bandeau-texts on the columns of Kom Ombo temple, a royal propaganda is strongly expressed through the phrases of those bandeau-texts. People are required to share the king in accomplishing his duties towards either deities or Egypt. Therefore, the motif rhyt-nb-dw3, as substitution of those people, is depicted on the bases of columns, directly beneath the lower bandeau-text, which contains the key-phrase to the scenes. It has the same direction like the king and the bandeau-texts.

\footnotetext{
${ }^{1}$ KO 309 C-D.

${ }^{2} \mathrm{KO} 285 \mathrm{C}$-D. Mut is the mistress of sky. In addition, the king is her beloved in the same bandeau-text.
} 


\section{Notes on the Bandeau-Texts of Columns of Kom Ombo Temple}

\section{Bibliography}

- Baumann, Stefan. Schatzkammern. Ihre Dekoration und Raumkonzeption in ägyptischen Tempeln der griechisch-römischen Zeit, SSR 19, 2018, 242-243, 370-373.

- Bedier, Shafia. Die Rolle des Gottes Geb in den ägyptischen Tempelinschriften der griechischrömischen Zeit. Hildesheimer Ägyptologische Beiträge 41, Hildesheim: Gerstenberg, 1995.

- Beylage, Peeter. 'Die Formel $\operatorname{ir}(i)=f \underline{d}(i)$ ' $n h$ in den Texten der 18. Dynastie', in GM 181, 2001, 19-26.

- Gee, John. 'A New Look at the di-`nh Formula', in Acts of the Tenth International Congress of Demotic Studies: Leuven, 26-30 August 2008, ed. M. Depauw et al., Leuven-Paris-Walpole, 2014, 73-82.

- Goyon, George. 'Les Travaux de Chou et les Tribulations de Geb', in Kemi 6, 1936, $1 \mathrm{ff}$.

- Gundlach, Rolf. "Ich gebe dir das Königtum der Beiden Länder": der ägyptische Tempel als politisches Zentrum', in 5. Ägyptischen Tempeltagung: Würzburg, 23-26. September, 1999, ed. Horst Beinlich, et al., Wiesbaden: Harrassowitz, 2002, 91-108.

- Gutbub, Adolphe. 'Kom Ombo', in Lexikon der Ägyptologie III, Wiesbaden: Otto Harrassowitz, 1981, 675-683.

- Gutbub, Adolphe. Textes fondamentaux de la théologie de Kom Ombo I (=BdE 47), Cairo: IFAO, 1973.

- Hölbl, Günther. A history of the Ptolemaic empire. Translated by T. Saavedra, London: Routledge 2001.

- Hölbl, Günther. Geschichte des Ptolemäerreiches: Politik, Ideologie und religiöse Kultur von Alexander dem Großen bis zur römischen Eroberung, Stuttgart: Theiss, 2004.

- Kees, Hermann. Der Götterglaube im alten Ägypten, $2^{\text {nd }}$ ed., Berlin: Akademie-Verlag, 1956.

- Kitchen, Kenneth. 'A note on Bandeau texts in New Kingdom temples', in Studien zu Sprache und Religion Ägyptens: zu Ehren von Wolfhart Westendorf, überreicht von seinen Freunden und Schülern 1, ed. Friedrich Junge, Göttingen: F. Junge, 1984, 547-553.

- Kurth, Dieter. 'Die Friese innerhalb der Tempeldekoration griechisch-römischer Zeit', in Aspekte spätägyptischer Kultur: Festschrift für Erich Winter zum 65. Geburtstag, ed. Martina Minas, et al., Mainz: Philipp von Zabern, 1994, 191-201.

- Kurth, Dieter. Einführung ins Ptolemäische: eine Grammatik mit Zeichenliste und Übungsstücken, vol. I., Hützel: Backe Verlag, 2007.

- Meeks, Demetri. 'Coptos et les chemins de Pount', in TOPOI Suppl. 3, 2002, 267-335

- Menu, Bernadette. 'Aspects de la fonction de juger dans l'Égypte pharaonique', in Droit et cultures 47 (1), 2004, 123-138.

- Minas, Martina. 'Die Dekorationstätigkeit von Ptolemaios VI. Philometor und Ptolemaios VIII. Euergetes II. an ägyptischen Tempeln (Teil 2)', in OLP 28, 1997, 87-121.

- Nutz, Rainer. 'Zur ideologischen Verortung von t3-ntr und Punt', in SAK 39, 2010, 281-288.

- Otto, Eberhard. ‘Ägypten im Selbstbewußtsein des Ägypters’, in Lexikon der Ägyptologie I, Wiesbaden: Otto Harrassowitz, 1975, 76-78.

- Otto, Eberhard. Gott und Mensch nach den ägyptischen Tempelinschriften der griechisch-römischen Zeit: eine Untersuchung zur Phraseologie der Tempelinschriften, Heidelberg: Carl Winter, Universitätsverlag, 1964.

- Pfeifer, Stefan. Die Ptolemäer im Reich der Kleopatra, Stuttgart: W. Kohlhammer, 2017.

- Pinch, Geraldine. Magic in Ancient Egypt, London: British Museum Press, 1994.

- Saleh, Abdelaziz. 'Notes on the Ancient Egyptian ta-netjer, 'God's-Land', in BIFAO 81, 1981, 107-117.

- Teeter, Emely. The presentation of Maat: ritual and legitimacy in ancient Egypt, SAOC 57, Chicago: The Oriental Institute of the University of Chicago, 1997. 


\section{Notes on the Bandeau-Texts of Columns of Kom Ombo Temple}

- Thissen, Heinz-Joseph. 'Kleopatra', in Lexikon der Ägyptologie III, Wiesbaden: Otto Harrassowitz 1981, 452-454.

- Tillier, Anaïs. 'Les colonnes de la cour du temple de Kôm Ombo: organisation et discours théologique du décor', in Der Ägyptische Tempel als ritueller Raum: Theologie und Kult in ihrer architektonischen und ideellen Dimension, Juni 2015, ed. Stefan Baumann, at al., Wiesbaden: Harrassowitz 2017, 107-125.

- Winter, Erich. Untersuchungen zu den ägyptischen Tempelreliefs der Griechisch-Römischen Zeit, Vienna: H. Böhlau Nachf, 1968.

- Yasuoka, Yoshifumi. Untersuchungen zu den Altägyptischen Säulen als Spiegel der Architekturphilosophie der Ägypter, QUIA Bd. II, Hützen: Backe Verlag 2016, pl. XIV.

- Yoyotte, Jean. 'Processions géographiques mentionnant le Fayoum et ses localités', in BIFAO 61, 1962, 79-138. 